-

Short Communication

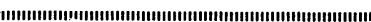

\section{GTPase Activity in Rice Plasma Membrane Preparation Enhanced by a Priming Effector for Plant Defence Reactions}

\author{
Yasuharu Sekizawa, Hideyuki Aoyama, \\ Makoto Kimura and Isamu YamaGUCHI* \\ Microbial Toxicology Laboratory, The Institute of \\ Physical and Chemical Research (RIKEN), \\ Hirosawa, Wako 351-01, Japan
}

(Received July 26, 1994;

Accepted February 20, 1995)

\section{INTRODUCTION}

Self-defence reactions against blast fungus are induced by a fungal proteoglucomannan elicitor at an early stage of infection in rice plant.1 Recent studies have revealed the involvement of signal transduction system, including phosphoinositidase $\mathrm{C}$ and $\mathrm{Ca}^{2+}$ (or calcium modulated protein) dependent protein kinase(s), in the early defence reactions in rice plant, leading to activation of $\mathrm{O}_{2} \cdot$ - forming system and phospholipase $\mathrm{A}_{2} .{ }^{2,3)}$ In addition to the resistance reactions triggered by the fungal elicitor, some non-antifungal chemical agents, such as 1,2-benzisothiazol$3(2 \mathrm{H})$-one 1,1-dioxide (BIT), an active form of probenazole, and $N$-cyanomethyl-2-chloroisonicotinamide (NCI) are known to act as priming effectors for acquired systemic resistance in rice plants. While the molecular mechanism by which these priming effectors induce resistance still remains to be elucidated, it has been demonstrated that NCI activates PI turn-over in elicitor-stimulated rice-embryo culture cells.4) The result suggests that the molecular target(s) of NCI resides in upstream of the phosphoinositidase $\mathrm{C}$ system coupled to the putative receptor for the elicitor, and that the action site of BIT might also be located in these systems. Thus we have focused our attention on the effects of the elicitor and BIT on the phosphoinositidase $\mathrm{C}$ system in rice plasma membrane. This paper deals with the preparation of the plasma membrane from rice leaves and the effect of BIT and/or the fungal elicitor on the GTPase activity in the preparation.

\footnotetext{
* To whom correspondence should be addressed.
}

\section{MATERIALS AND METHODS}

\section{Reagents}

Salicylhydroxamic acid (SHAM), phenylmethylsulfonyl fluoride (PMSF), 2-( $N$-morpholino)ethanesulfonic acid (MES), dithiothreitol (DTT), tris(hydroxymethyl)aminomethane (Tris), bovine serum albumin (BSA), creatine phosphokinase and nucleoside diphosphate kinase were obtained from Sigma Chemical Co., U.S.A. $\left[\gamma-{ }^{32} \mathrm{P}\right] \mathrm{GTP}(30 \mathrm{Ci} / \mathrm{mmol})$ was purchased from Amersham Japan. Other reagents used were the highest grade commercially available.

\section{Preparation of Rice Plasma Membrane and Blast Fungus Elicitor}

In this study, we used the same lot of plasma membrane stock prepared from the rice seedlings grown in a phytotron from May to October. Rice blades at 4 to 5 leaf stage of seedlings (cv. Aichiasahi) were excised and washed with water. The blades (ca. $30 \mathrm{~g}$ fresh wt.) were cut into fine cross-sections and homogenized in $300 \mathrm{ml}$ of homogenization medium (5 mM EGTA, $5 \mathrm{~mm}$ EDTA, $10 \mathrm{~mm} \quad \mathrm{NaF}, 2.5 \mathrm{~mm} \quad \mathrm{Na}_{2} \mathrm{~S}_{2} \mathrm{O}_{4}, 1 \mathrm{~mm}$ DTT, $4 \mathrm{~mm}$ SHAM, $2 \mathrm{~mm}$ PMSF, $0.5 \%$ BSA, $0.3 \mathrm{~m}$ sucrose, and $50 \mathrm{~mm}$ MES-Tris; $\mathrm{pH} 7.6$ ) using a Nissei AM-8 homogenizer for $1 \mathrm{~min}$ for 3 times at $4^{\circ} \mathrm{C}$. The homogenate was filtered through a double-gauze and $80 \mu \mathrm{m}$ nylon-meshes. The filtrate was centrifuged at $10,000 \times g$ for 30 min, and an equal volume of suspension medium $\left(0.25 \mathrm{~m}\right.$ sucrose and $10 \mathrm{~mm} \mathrm{KH}_{2} \mathrm{PO}_{4} / \mathrm{K}_{2} \mathrm{HPO}_{4} ; \mathrm{pH}$ 7.8) was added to the supernatant. The mixture was ultracentrifuged $(100,000 \times g, 30 \mathrm{~min})$ to obtain the sediment of microsomal fraction and the precipitate was resuspended in $6 \mathrm{ml}$ of the suspension medium. The plasma membrane fraction was purified from the crude suspension by the aqueous two-phase partition according to the procedures reported ${ }^{5-8)}$ with some modifications as follows. The mixture of $6 \%(\mathrm{w} / \mathrm{w})$ of each Dextran T-500 and polyethylene glycol 4000 in the suspension medium was added to $1 \mathrm{ml}$ of the suspension of crude plasma membrane to give a total weight of $9 \mathrm{~g}$. Then $\mathrm{NaCl}$ was gradually added to the mixture with gentle stirring to make the concentration from 20 to $60 \mathrm{~mm}$, and the resultant mixture was centrifuged at $1500 \times g$ for $5 \mathrm{~min}$. To the upper phase, $20 \mathrm{ml}$ of isolation medium $(10 \mathrm{~mm} \mathrm{NaF}, 2.5 \mathrm{~mm}$ $\mathrm{Na}_{2} \mathrm{~S}_{2} \mathrm{O}_{4}, 1 \mathrm{~mm}$ DTT, $2 \mathrm{~mm}$ PMSF, $0.3 \mathrm{~m}$ sucrose, 
and $50 \mathrm{~mm}$ MES-Tris; $\mathrm{pH}$ 7.6) was added and shaken. Following ultracentrifugation at $100,000 \times g$ for $60 \mathrm{~min}$, the pellets were resuspended in $2 \mathrm{ml}$ of the diluted isolation medium (10-folds with deionized water) and stored at $-80^{\circ} \mathrm{C}$, if necessary. The stocked membrane preparation was used for the experiment within a week.

The preparation of proteoglucomannan elicitor (25 kDa fragment) from blast fungus ( $\mathrm{H} 373$ : race 007) was performed according to Kanoh et al..$^{2)}$

\section{Assay of Plasma Membrane Preparation}

The micro-assays of inorganic orthophosphate (Pi) and total protein were done according to Heinonen \& Lahti $^{9)}$ and Bradford, ${ }^{10)}$ respectively. Purity of plasma membrane preparation was assessed by measuring the activity of marker enzymes, i.e., $\mathrm{Na}_{3} \mathrm{VO}_{4}$ sensitive ATPase, inosine diphosphatase (IDPase) and NADH-cyt. c reductase as described previously. ${ }^{7,11)}$

\section{Determination of GTPase Activity}

Determination of rice plasma membrane GTPase activity was achieved according to Shenker et al. ${ }^{12)}$ Aktories \& Jakobs, ${ }^{13)}$ and Cassel $\&$ Selinger ${ }^{14)}$ with some modifications. The assay system contained $0.67 \mu \mathrm{M}\left[\gamma_{-}{ }^{32} \mathrm{P}\right] \mathrm{GTP}(4.4$ $\left.\times 10^{6} \mathrm{dpm}\right), 0.1 \mathrm{~mm}$ EGTA, $2 \mathrm{~mm} \mathrm{MgCl}_{2}, 1 \mathrm{~mm}$ DTT, $0.1 \mathrm{~mm}$ ATP, $5 \mathrm{~mm}$ phosphocreatine (Tris salt), 10 units creatine phosphokinase, and 10 units nucleoside diphosphate kinase in $50 \mathrm{~mm}$ BisTris- $\mathrm{HCl}(\mathrm{pH}$ 7.0). The final volume was $100 \mu \mathrm{l}$, and sodium deoxycholate (DOC, $0.05 \% \mathrm{w} / \mathrm{v})$, BIT $(1 \mathrm{~mm})$ and/or blast fungus elicitor $(5 \mu \mathrm{g})$ were also included in the reaction mixture when necessary. Reactions were initiated by the addition of rice plasma membrane preparation (eq. to $25 \mu \mathrm{g}$ plasma membrane protein) to the mixture at $25^{\circ} \mathrm{C}$ and were terminated by the addition of $750 \mu \mathrm{l}$ of cold $5 \%(\mathrm{w} / \mathrm{v})$ activated charcoal in $20 \mathrm{~mm}$ phosphoric acid. Tubes were fully shaken and centrifuged $\left(6000 \times g\right.$ for $20 \mathrm{~min}$ at $\left.4^{\circ} \mathrm{C}\right)$ and ${ }^{32} \mathrm{P}$ in $425 \mu \mathrm{l}$ of each supernatant was counted in a sintillation spectrometer using Cerenkov radiation. ${ }^{22}$

\section{RESULTS AND DISCUSSION}

Preparation of rice plasma membrane were carried out by the two-phase partitioning method, fundamentally following the procedures developed for orchard grass (Dactylis glomerata L.), ${ }^{5)}$ mung bean (Vigna radiata L.), ${ }^{6)}$ and corn (Zea mays L.). ${ }^{7)}$ However, the optimal concen-

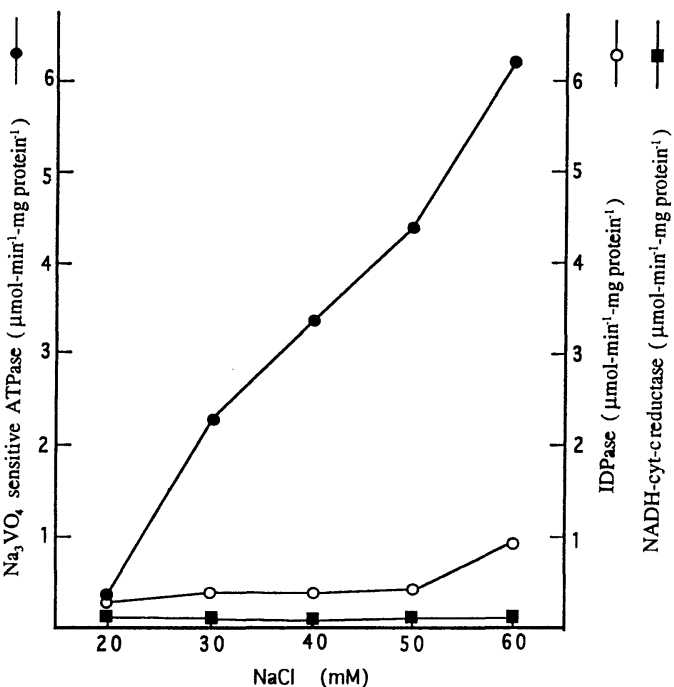

Fig. 1 Relationships between membrane-bound enzymes and sodium chloride concentration in the partition mixture.

-: $\mathrm{Na}_{3} \mathrm{VO}_{4}$-sensitive ATPase, $\bigcirc$ : IDPase, $\mathrm{NADH}$-cyt. c reductase.

Table 1 Effects of inhibitors on $\mathrm{Mg}^{2+}$-ATPase in the plasma membrane preparation.

\begin{tabular}{lrcc}
\hline \multirow{2}{*}{ Addition $(\mathrm{mm})$} & \multicolumn{2}{c}{$\mathrm{Mg}^{2+}$-ATPase activity $\left.(\%)^{\mathrm{a}}\right)$} \\
\cline { 3 - 4 } & $\left.\mathrm{NaCl}: 50 \mathrm{mM}^{\mathrm{b}}\right)$ & $\left.\mathrm{NaCl}: 60 \mathrm{mM}^{\mathrm{b}}\right)$ \\
\hline $\mathrm{KNO}_{3}$ & $(50 \mathrm{~mm})$ & 14 & 6 \\
$\mathrm{NaN}_{3}$ & $(1 \mathrm{~mm})$ & 10 & 8 \\
$\mathrm{Na}_{3} \mathrm{VO}_{4}$ & $(0.1 \mathrm{mM})$ & 84 & 86 \\
\hline
\end{tabular}

a) Figures indicate inhibition $\%$ by inhibitors on $\mathrm{Mg}^{2+}$-ATPases in rice-blade plasma membrane preparation.

b) $\mathrm{NaCl}$ concentrations used for preparation of rice plasma membrane fraction.

tration of $\mathrm{NaCl}$ in the partition system appeared to differ significantly depending on plant species used for the experiments. In contrast to the membrane preparation described in the previous papers, ${ }^{5,6)}$ a high concentration of $\mathrm{NaCl}(50-60$ $\mathrm{mm}$ ) gave the best separation profile of the plasma membrane fraction in rice plant as assessed by the distribution of marker enzymes (Fig. 1). Only low contamination of Golgi membranes with IDPase activity was observed and negligible NADH-cyt. c reductase activity specific for ER was detected. The ATPase activity in the preparation was characterized by 


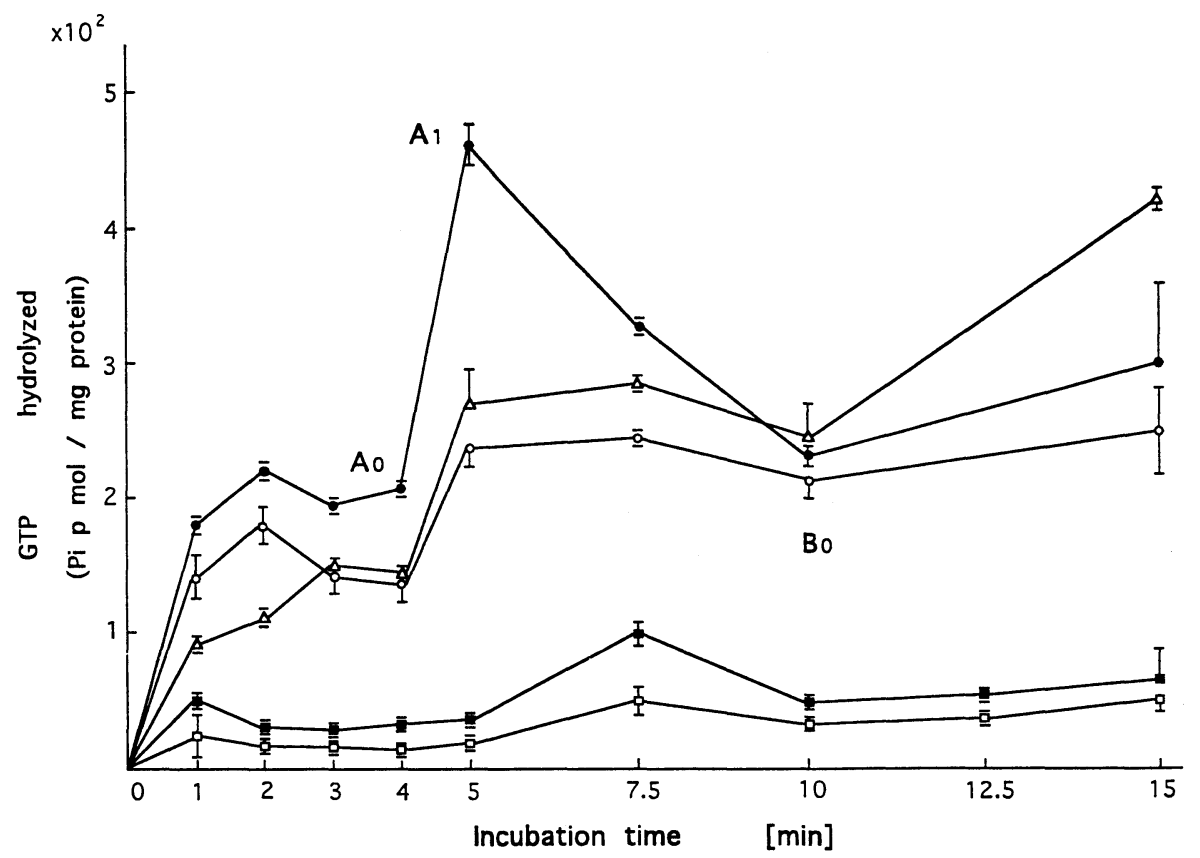

Fig. 2 Effects of BIT and blast fungus proteoglucomannan elicitor on GTPase activity in riceblade plasma membrane preparation.

$\square:$ PM without DOC, $\square: P M$ with DOC, $\triangle: P M+D O C+$ elicitor, $\bigcirc: P M+D O C+B I T, \bullet: P M+$ DOC+BIT+elicitor. PM: rice-blade plasma membrane preparation, DOC: sodium deoxycholate, BIT: 1, 2-benzisothiazol-3 $(2 H)$-one 1, 1-dioxide. The incubations were conducted at $25^{\circ} \mathrm{C}$ for each indicated time. Bars indicate standard error in duplicated measurements.

determining its sensitivity to specific inhibitors, which showed quite low contamination of membranes of tonoplasts (sensitive to $\mathrm{KNO}_{3}$ ) and mitochondria (sensitive to $\mathrm{NaN}_{3}$ ), as shown in Table 1. These results demonstrate the isolated plasma membrane fraction to be suitable for further biochemical analyses.

Figure 2 shows the stimulation of GTPase activity in plasma membrane by the fungal elicitor and/or BIT. In either case, an immediate increase of $\mathrm{Pi}$ release was observed (0-1 min) after initiation of the reaction. Following the constant state lasting for $3 \mathrm{~min}$ (1-4 min), an abrupt reelevation of GTPase activity was observed (4-5 min). The level of elevation was highest in the presence of both elicitor and BIT $\left(\mathrm{A}_{0}-\mathrm{A}_{1}\right.$ in Fig. 2), but the amount of released $\mathrm{Pi}$ gradually decreased after $A_{1}$. The apparent downwards regulation $\left(\mathrm{A}_{1}-\mathrm{B}_{0}\right)$ may be attributed to the function of putative $\mathrm{H}^{+}$translocating ATPase, $\mathrm{Ca}^{2+}-\mathrm{H}^{+}$antiporter, or $\mathrm{Ca}^{2+}$ translocating ATPase existing in the rice plasma membranes, though the precise explanation is not available at present. However, such profiles as shown in
Fig. 2 were repeatedly obtained under conditions described above.

The GTPase reached an activated state quite effectively in response to the existence of BIT, a priming effector for acquired systemic resistance in rice plant, which supports our hypothesis that the activation of putative G-protein may be involved in the signaling pathway leading to earlier biochemical defence reactions. Naim et al. recently reported that amphiphilic sweeteners, such as aspartame and soluble saccharin (sodium salt of BIT) directly activate $\mathrm{G}_{\mathrm{i}} / \mathrm{G}_{0}$-proteins and transducin, which belong to the same G-protein superfamily in mammalian systems. ${ }^{15)}$ Our present study suggests that BIT may function as G-protein activators in rice plants as well. The hypothesis should be confirmed by the future G-protein binding assays using the plasma membrane preparations isolated from rice blades by the procedures described.

In summary, the rice plasma membrane fraction prepared by the two-phase partitioning method proved to exhibit GTPase activity which 
is stimulated by blast fungus proteoglucomannan and/or BIT, a priming effector, in the presence of DOC. The result suggests that BIT enhances the potential plant defence abilities, either directly or indirectly, through activation of putative G-proteins.

\section{ACKNOWLEDGMENTS}

We thank Drs. Daijiro Hosokawa and Tohru Teraoka, Tokyo University of Agriculture and Technology for their invaluable support and discussion throughout the study, and to Ms. Shigeko Sekido in our lab. for her skillful supports to maintain rice seedlings in phytotron. The research was in part supported by the grant for "Biodesign Research Program" from The Institute of Physical and Chemical Research (RIKEN).

\section{REFERENCES}

1) I. Yamaguchi \& Y. Sekizawa: Plant Prot. 47, 218 (1993) (in Japanese)

2) H. Kanoh, M. Haga, M. Iwata \& Y. Sekizawa: J. Pesticide Sci. 18, 299 (1993)

3) H. Kanoh, M. Haga \& Y. Sekizawa: J. Pesticide Sci. 18, 325 (1993)

4) K. Seguchi, S. Sekido \& I. Yamaguchi: $J$. Pesticide Sci. 17, 123 (1992)

5) S. Yoshida, M. Uemura, T. Niki, A. Sakai \& L. V. Gusta: Plant Physiol. 72, 105 (1983)

6) S. Yoshida, T. Kawata, M. Uemura \& T. Niki: Plant Physiol. 80, 152 (1986)

7) M. Kasai \& S. Muto: J. Membr. Biol. 114, 133
(1990)

8) M. Staal, C. Hommels \& D. Kuiper: Physiol. Plant. 70, 461 (1987)

9) J. K. Heinonen \& R. J. Lahti: Anal. Biochem. 113, 313 (1981)

10) M. M. Bradford: Anal. Biochem. 58, 248 (1976)

11) D. J. Bowles \& H. Kauss: Biochim. Biophys. Acta 443, 360 (1976)

12) A. Shenker, P. Goldsmith, C. G. Unson \& A. M. Spiegel: J. Biol. Chem. 266, 9309 (1991)

13) K. Aktories \& K. H. Jakobs: FEBS Lett. 130, 235 (1981)

14) D. Cassel \& Z. Selinger: Biochim. Biophys. Acta 452, 538 (1981)

15) M. Naim, R. Seifert, B. Nürnberg, Grünbaum \& G. Schultz: Biochem. J. 297, 451 (1994)

\section{要 約}

\section{病害抵抗性付与剤によるイネ葉細胞形質標品 GTP} アーゼ活性の穴進

関沢泰治, 青山秀幸, 木村 真, 山口 勇 イネ葉細胞のミクロソーム画分をポリマー二相分離法で分別 し，他の膜成分の混入の少ない形質膜標品を得た。との形質膜 標品にイネいもち病菌由来のプロテオグルコマンナン エリシ ターを加えるととにより，膜結合 GTP アーゼの活性増大が誌 められた．またプロベナゾールの活性代謝物 BIT の存在下で, このエリシターの効果は顕著に高進した。これらの結果は, BIT 等の全身獲得抵抗性付与剂による病害抵抗性の早期成立に 関わる GTP 結合タンパク質が, イネ葉細胞の膜情報伝達系に 存在するてとを示唆している. 